\title{
Influence of Dysmenorrhea and Menorrhagia on Academic Performance among Female Students in Tertiary Institutions in Ondo State Nigeria
}

\author{
Caroline Funmbi Akinnubi, ${ }^{1, *}$ \\ ${ }^{1}$ Department of Physical and Health Education, Obafemi Awolowo University, Ile Ife, Osun State, Nigeria \\ *Correspondence: Department of Physical and Health Education, Obafemi Awolowo University, Ile Ife, Osun State, \\ Nigeria. Tel: 234-703-116-4469. E-mail: fakinnubi@yahoo.com
}

Received: March 23, 2016 Accepted: April 10, 2016 Online Published: May 19, 2016

doi:10.5430/wjss.v3n2p34 URL: http://dx.doi.org/10.5430/wjss.v3n2p34

\begin{abstract}
Objective: The study examined the influence of dysmenorrhea and menorrhagia on academic performance among tertiary institution female students in Ondo State, Nigeria.

Methods: A total of 150 female respondents were selected using purposive sampling technique in the institutions. A validated self-structured questionnaire consisting 2 sections were used for the study. Section A sought the socio-demographic data while section B was designed to elicit information on dymenorrhoea, menorrhgia, and academic performance. The data collected were computed using simple percentages and t-test analysis at 0.05 alpha level of significance. Verbal interview with 15 female students were also used for the study.

Results: The findings of this study revealed that very many of respondents identified that they did not engage in exercise at all during menstrual period, they were aware of dysmenorrhea and menorrhagia, and that they experienced various symptoms/dysfunction. It was further revealed that many students managed to go for lectures, and usually experienced dysmenorrhea (severe pain) and menorrhagia (heavy bleeding), which disallowed them to be attentive in class. It was also revealed that there was a significant difference of dysmenorrheal and menorrhagia on academic performance between tertiary institutions female students.
\end{abstract}

Conclusion: Based on the findings, the paper recommends that the university authority should implement practical compulsory course relating to exercise/sports as special elective course to ease them from pains. Seminars and media could also serve of a source of passing information to students.

Keywords: influence, university, female students, dysmenorrhea, menorrhgia, academic performance

\section{Introduction}

Dysmenorrhea is a general problem in women of reproductive age. It is a serious pain and very severe during menstruation (Campbell, and McGrath1997). Dysmenorrhoea, or painful menstruation is a painful cramps that start a few hours before the commencement of bleeding, that could be for hours or days (Hacker, Gambone, and Hobel, 2010 \& Durain 2004). According to Hao, and Liu, (2000), investigations on dysmenorrheal data were concern with menstrual pain that occurred once a month or often. Menorrhagia is a heavy and prolonged menstrual bleeding (Grant, Gallier, Fahey, Pearson, \& Sarangi, 2000; Kamatemesi-Mugisha, Oryem-Origa, \& Olwa-Odyek 2007).

Dysmenorrhea is grouped into two main types: Primary dysmenorrhoea is concern with pelvic pain but without pelvic pathology before and/or during menstruation, while Secondary dysmenorrhea is menstrual pain that is related with fundamental pathology, which could be years after the start of the menstrual function (Dawood 1985, Campbell et al 1999). According to Hacker, Gambone, Hobel, Hacker and Moore's (2010), dysmenorrhoea may be primary, when there is no particular cause or secondary when it includes organic pelvic diseases. Primary dysmenorrhoea occurs naturally between the ages of 17 and 22 years, while secondary dysmenorrhoea is more frequent in older women. Dysmenorrhoea is usually connected with symptoms like lower back pain, headache, nausea, vomiting, diarrhoea, and fatigue (Hacker et al 2010). In the same vein, Klein (1981) said primary dysmenorrhea is a painful menstruation without pelvic problem, and could involve vomiting, fatigue, back pain, headaches, dizziness, and diarrhea. The author also said that secondary dysmenorrhea although painful, is with pelvic problem. 
According to a study conducted by Titilayo, Banjo,Agunbiade, \& Lawani (2009, menorrhagia was significant among female students with dizziness, headache, depression and irritation, whose menstrual abnormal function or uneasiness did call for medical awareness. Menorrhagia was rarely frequent with $21 \%$ than dysmenorrhoea with $64 \%$ respondents. Menstrual period among women may cause headache, abdominal pain, and may be disturbed from real daily activities (Davis \& Westhoff, 2001; Liasu, Orji, \& Lawani 2008). According to Campbel et al (1997), and Hillen et al (1999), dysmenorrhea is a common aberration among female adolescents with a regularity of $60 \%$ to 93\%. Untreated primary dysmenorrhoea starts from school absenteeism to commotion of relationships with family and friends (Wong, and Khoo. 2010, Nwankwo, Aniebue, and Aniebue, 2010, Eryilmaz, Ozdemir, and Pasinlioglu, 2010).

Dysmenorrhea occurred among 56.4\% students. It became more severe, when dysmenorrheal became longer. The percentages of students taking medicine during dysmenorrhea were $4.0 \%, 13.3 \%$ and 23.7\%, respectively (Hong-Gui Zhou1, Zheng-Wei Yang, Students Group 2010). The prevalence of dysmenorrheal was investigated among university/college students in china, reported 31.5\% to 41.9\% (Guo, et al 1994 \& Zhan, 2003) and from 57.1\% to 79.4\% (Wang, et al 2008 \& Yu et al 2008). In studies conducted by Thomas, Okonofua, and Chiboka, (1990) \& Cakir, Mungan, Karakas, Girisken, and Okten, (2007), rate of incidence of dysmenorrhea were common among Nigerian and Turkey university students. Sports according to Cagical (1990) are acclaimed to represent an intergral part of educational programme that contributes to students' welfare as well as students potentials. Darst and Pangrazi, (2006); Pangrazi (2006) contended that sports play many roles, which are beneficial to not only individual but also to groups depending on how it is viewed and what can be achieved. Dysmenorrhea can cause school absenteeism, may have negative effect on academic, and sports activities among many female adolescents (Chantay, Mariam, and Steve, 2000). Dysmenorrhoea and menorrhagia commonly limit daily home regular task, concentration in class and attending school (El-Gilany et al., 2005). In the same vein, Hillen and Grbavac (1999) said that adolescents with dysmenorrhea did report that it had harmful outcome on their academic performance, social and sports activities. According to Titilayo, Banjo, Agunbiade, and Lawani (2009), menorrhagia appeared as the principal factor affecting their daily school activities. In a study conducted by Liliwati, Verna, and Khairani,(2007), the students reported that dysmenorrhoea affected their concentration in class and called for absenteeism, The level of pain correlated completely thereby limiting their school activities.

In a study conducted by Banikarim, Chacko, and Kelder (2000) menstrual pain was significantly associated with school absenteeism and decreased academic performance. Absenteeism from both classes and work by the female students did occur as a result of dysmenorrhea (Dawood 1990). In a study conducted by Alaettin, Unal, Tozun, Arslan, and Calik (2010), there was no statistical significant difference between those with dysmenorrhea and those without dysmenorrhea, It was also reported in a study conducted by Cakir, Mungan, Karakas, Girisken, and Okten (2007), that the prevalence of dysmenorrhea was high with $89.5 \%$ among the respondents. There was no appropriate and no sufficient information about menstrual problems among very many of the adolescents (Titilayo et al 2009). According to Hillen et al. (1999), some young women lack the awareness and understanding of helpful treatment of dysmenorrhoea and other related discomforts of menstrual period.

The tertiary institution students may think that the menstrual period and problems are regular monthly activities, but are not aware of the terms dysmenorrheal and menorrhagia or what could be the remedy or intervention, and the appropriate information necessary for this; hence, this study.

\section{Problem of the Study}

Dysmenorrheal and Menorrhagia have been the common problem of adolescent students which may influence their ability to concentrate in class. Therefore the students' awareness and experience about dysmenorrheal and menorrhagia, how these affect their academic activities and the possible cases of irregularities among them during their menstrual period are not known, hence this study.

\section{Objectives}

This study specifically examined the students' awareness and experience about dysmenorrheal and menorrhagia as it affects their academic activities and the possible cases of irregularities among them during their menstrual period. 


\section{Research Questions}

1) Are you awareness of dysmenorrhea (severe pain) and menorrhgia (heavy bleeding) during menstruation?

2) Which of the following Symptoms/dysfunction do you experience during your menstrual period?

3) How often do you go to school and stay in class during your menstrual period?

4) Do you engage in exercise to ease your menstrual period?

\section{Research Hypothesis}

1) There is no significantly difference of menorrhagia and dysmenorrhea on academic performance between tertiary institutions female students.

\section{Methodology}

\subsection{Research design}

Descriptive survey design was adopted for the study so as to explain the situation as it is.

\subsection{Participant}

The population of the study comprised of all the female students in tertiary institutions in Ondo State. Adeyemi college of Education and Adekunle Ajasin University female students was selected for the study using convenient random sampling.

\subsection{Sampling Procedure}

A total of 85 female respondents from Adekunle Ajasin University and 65 Adeyemi college of Education making a total of 150 students were selected using purposive sampling technique. A total of 16 female students were also interviewed verbally relating to menorrhagia and dysmenorrhea to elicit some vital information for this study.

\subsection{Research Instrument}

A validated self-developed structured questionnaire titled "influence of academic performance on dysmenorrhea and menorrhagia of university female students (IAPDM), this contained two sections. Section A of the questionnaire was the demographic aspect such as school, age and denomination. Section B was developed to elicit information on academic performance, dysmenorrheal and menorrhgia. on 'Strongly Agreed, Agreed, Disagreed', Strongly Disagreed' responses. The questionnaire was validated by two research experts for content validity, and was subjected to a test-retest reliability index of 0.85 which was deemed fit for the study. The questionnaire was administered by the researcher with help of the three research assistants on the respondents.

\subsection{Data Analysis}

Data collected were analyzed simple percentages and t-test at 0.05 alpha levels.

Table 1. Demographic Characteristics of the respondents ( $\mathrm{N}=150)$

\begin{tabular}{llllll}
\hline Variables & Responses & \multicolumn{2}{l}{ University female students (85) } & $\begin{array}{l}\text { College of } \\
\text { students (65) }\end{array}$ & Education female \\
\cline { 3 - 6 } & & Frequency & Percentage & Frequency & Percentage \\
\hline \multirow{2}{*}{ Age } & 19yrs and below & 12 & $(8 \%)$ & 09 & $(6 \%)$ \\
& 20-25yrs & 23 & $(15.3 \%)$ & 25 & $(16.7 \%)$ \\
& $26-30 y r s$ & 35 & $(23.3 \%)$ & 19 & $(12.7 \%)$ \\
& 31-35yrs & 15 & $(10 \%)$ & 12 & $(8 \%)$ \\
\hline \multirow{2}{*}{ Religion } & Christianity & 52 & $(34.7 \%)$ & 48 & $(32 \%)$ \\
& Islam & 21 & $(14 \%)$ & 13 & $(8.7 \%)$ \\
& Others & 12 & $(8 \%)$ & 04 & $(2.7 \%)$ \\
\hline
\end{tabular}

The respondents' location was Adekunle Ajasin University Akungba Akoko and Adeyemi college of Education Ondo in Ondo state. The age range was between 19-35years. Very many of the respondents were Christians both in the two tertiary institutions. 
Table 2. Awareness of Dysmenorrhea (Severe Pain) and Menorrhgia (Heavy Bleeding) During Menstruation

\begin{tabular}{|c|c|c|c|c|c|}
\hline $\mathbf{S} / \mathbf{N}$ & VARIABLES & $\begin{array}{l}\text { Strongly } \\
\text { Agreed \% }\end{array}$ & $\begin{array}{l}\text { Agreed } \\
\%\end{array}$ & $\begin{array}{l}\text { Disagreed } \\
\%\end{array}$ & $\begin{array}{l}\text { Strongly } \\
\text { Disagreed \% }\end{array}$ \\
\hline 1. & Menorrhagia is a heavy bleeding during menstruation & $80(53.3 \%)$ & $35(23.3 \%)$ & $15(10 \%)$ & $20(13.3 \%)$ \\
\hline 2. & Dysmenorrhea is a severe pain during menstruation & $84(56 \%)$ & $27(18 \%)$ & $26(17.3 \%)$ & $13(8.7 \%)$ \\
\hline 3. & $\begin{array}{l}\text { Dysmenorrhoea is of two types, Primary and } \\
\text { Secondary Dysmenorrhoea }\end{array}$ & $88(58.7 \%)$ & $28(18.7 \%)$ & $22(14.7 \%)$ & $12(8 \%)$ \\
\hline 4. & $\begin{array}{l}\text { Primary dysmenorrhea is a painful menstruation } \\
\text { without pelvic abnormalities. }\end{array}$ & $72(48 \%)$ & $42(28 \%)$ & $18(12 \%)$ & $18(12 \%)$ \\
\hline 5. & $\begin{array}{l}\text { Primary dysmenorrhea may be associated with fatigue } \\
\text { and dizziness. and diarrhea. }\end{array}$ & $69(46 \%)$ & $45(30 \%)$ & $20(13.3 \%)$ & $16(10.7 \%)$ \\
\hline 6. & $\begin{array}{l}\text { Primary dysmenorrhea can be associated with back } \\
\text { pain, and abdominal pain. }\end{array}$ & $75(50 \%)$ & $42(28 \%)$ & $18(12 \%)$ & $15(10 \%)$ \\
\hline 7. & $\begin{array}{l}\text { Primary dysmenorrhoea is associated with nausea and } \\
\text { vomiting. }\end{array}$ & $58(38.7 \%)$ & $35(23.3 \%)$ & $34(22.7 \%)$ & $13(8.7 \%)$ \\
\hline 8. & $\begin{array}{l}\text { Primary dysmenorrhea can be associated with } \\
\text { headaches. }\end{array}$ & $58(38.7 \%)$ & $60(40 \%)$ & $13(8.7 \%)$ & $19(12.7 \%)$ \\
\hline 9. & $\begin{array}{l}\text { Secondary dysmenorrhea is a painful menstruation } \\
\text { with pelvic abnormalities. }\end{array}$ & $65(43.3 \%)$ & $41(27.3 \%)$ & 23(15.3\%) & $21(14 \%)$ \\
\hline 10. & $\begin{array}{l}\text { Secondary dysmenorrhoea is commonly associated } \\
\text { with systemic symptoms like lower back pain }\end{array}$ & $60(40 \%)$ & $58(38.7 \%)$ & $19(12.7 \%)$ & $13(8.7 \%)$ \\
\hline
\end{tabular}

Table 2 above shows that the respondents strongly agreed and agreed to the following, a total of 80 (53.3\%) and $35(23.3 \%)$ respondents were aware that menorrhagia is a heavy bleeding during menstruation respectively, while 84(56\%) and 27(18\%) respondents were aware that dysmenorrhea is a severe pain during menstruation. A total of $72(48 \%)$ and $42(28 \%)$ respondents were aware that primary dysmenorrhea is a painful menstruation without pelvic abnormalities, while 65(43.3\%) and 41(27.3\%) respondents were aware that secondary dysmenorrhea is a painful menstruation with pelvic abnormalities. A total of $75(50 \%)$ and $42(28 \%)$ respondents were aware that primary dysmenorrhea can be associated with back pain, and abdominal pain, while 60(40\%) and 58(38.7\%) respondents were aware that secondary dysmenorrhoea is commonly associated with systemic symptoms like lower back pain,

Table 3. Symptoms/Dysfunction You Experience During Your Menstrual Period

\begin{tabular}{|c|c|c|c|c|c|}
\hline $\mathbf{S} / \mathbf{N}$ & Variables & $\begin{array}{l}\text { Strongly } \\
\text { Agreed \% }\end{array}$ & Agreed \% & $\begin{array}{l}\text { Disagreed } \\
\%\end{array}$ & $\begin{array}{l}\text { Strongly } \\
\text { Disagreed \% }\end{array}$ \\
\hline 1 & $\begin{array}{l}\text { I usually experience dysmenorrhea } \\
\text { (severe pain) during menstruation }\end{array}$ & $65(43.3 \%)$ & $45(30 \%)$ & $24(16 \%)$ & $16(10.6 \%)$ \\
\hline 2. & $\begin{array}{l}\text { I usually experience menorrhagia (heavy } \\
\text { bleeding) during menstruation }\end{array}$ & 75 (50\%) & $55(36.7 \%)$ & $22(14.7 \%)$ & $08(5.3 \%)$ \\
\hline 3. & I do experience diarrhea. & 10(6.7\%) & $18(12 \%)$ & 74(49.3\%) & 48(32\%) \\
\hline 4. & I do experience headaches. & $20(13.3 \%)$ & $68(45.3 \%)$ & $18(12 \%)$ & $49(32.7 \%)$ \\
\hline 5. & I do experience nausea and vomiting & $52(34.7 \%)$ & $26(17.3 \%)$ & $55(36.7 \%)$ & $22(4.7 \%)$ \\
\hline 6. & $\begin{array}{l}\text { I do experience painful pelvic } \\
\text { abnormalities. }\end{array}$ & $56(37.3 \%)$ & $28(18.7 \%)$ & $48(32 \%)$ & $18(12 \%)$ \\
\hline 7. & $\begin{array}{l}\text { I do experience back pain, and } \\
\text { abdominal pain }\end{array}$ & $69(46 \%)$ & $23(15.3 \%)$ & $10(6.7 \%)$ & $48(32 \%)$ \\
\hline 8. & I do experience fatigue and dizziness, & $50(33.3 \%)$ & $30(20 \%)$ & $45(30 \%)$ & $25(16.7 \%)$ \\
\hline 9. & I do experience lower back pain & $46(30.7 \%)$ & 35 (23.3\%) & $32(21.3 \%)$ & $38(25.3 \%)$ \\
\hline
\end{tabular}

Table 3 above shows that 65(43.3\%) and 45(30\%) respondents strongly agreed and agreed that they usually experienced dysmenorrhea (severe pain) during menstruation respectively, while 75 (50\%) and 55 (36.7\%) respondents strongly agreed and agreed that they usually experience menorrhagia (heavy bleeding) during menstruation respectively. A total of 56(37.3\%) respondents strongly agreed and 28(18.7\%) respondents agreed that they experienced painful pelvic abnormalities, while 69(46\%) respondents strongly agreed and 23(15.3\%) 
respondents agreed that they experienced back pain and abdominal pain. A total of 46(30.7\%) respondents strongly agreed and 35 (23.3\%) respondents agreed that they experienced lower back pain.

Table 4. Frequency of Staying in the Campus and the Lecture Room during Your Menstrual Period

\begin{tabular}{|c|c|c|c|c|c|}
\hline $\mathbf{S} / \mathbf{N}$ & Variables & $\begin{array}{l}\text { Strongly } \\
\text { Agreed }\end{array}$ & Agreed & Disagreed & $\begin{array}{l}\text { Strongly } \\
\text { Disagreed }\end{array}$ \\
\hline 1. & $\begin{array}{l}\text { I manage to go for lectures throughout my menstrual } \\
\text { period }\end{array}$ & $94(62.7 \%)$ & $33(22 \%)$ & $12(8 \%)$ & $11(7.3 \%)$ \\
\hline 2. & $\begin{array}{l}\text { I go to the campus for the first and the last day of my } \\
\text { menstrual period, because of pains and heavy bleeding } \\
\text { occasionally }\end{array}$ & $07(4.7 \%)$ & $08(5.3 \%)$ & $62(41.3 \%)$ & $51(34 \%)$ \\
\hline 3. & $\begin{array}{l}\text { my room for the period of my menstruation } \\
y\end{array}$ & $19(12.7 \%)$ & $10(6.7 \%)$ & $51(34 \%)$ & $70(46.7 \%)$ \\
\hline 4. & $\begin{array}{l}\text { to the campus during my menstruation due } \\
\text { rrheal occasionally }\end{array}$ & $11(7.3 \%)$ & $09(6 \%)$ & $52(34.7 \%)$ & $53(35.3 \%)$ \\
\hline 5. & $\begin{array}{l}\text { I do not go to the campus during my menstruation due } \\
\text { to Menorrhagia occasionally }\end{array}$ & $10(6.7 \%)$ & $08(5.3 \%)$ & $61(40.7 \%)$ & $47(31.3 \%)$ \\
\hline 6. & ally concentrate in the lecture room/ theatre & $54(36 \%)$ & & & $19(12.7 \%)$ \\
\hline 7. & I do sleep through the hours of lecture occasionally & $15(10 \%)$ & $17(11.3 \%)$ & $60(40 \%)$ & $58(38.7 \%)$ \\
\hline
\end{tabular}

From table 4 above, it was observed that 94(62.7\%) and 33 (22\%)respondents strongly agreed and agreed that they managed to go for lectures throughout their menstrual period respectively, while 19 (12.7\%)and 08(5.3\%) respondents strongly agreed and agreed that they did stay in their room for the period of their menstruation occasionally respectively. A total of 11(7.3\%) respondents strongly agreed and 09(6\%) respondents agreed that they did not go to the campus during their menstruation due to dysmenorrheal occasionally, while 54(36\%) respondents strongly agreed and $24(16 \%)$ respondents agreed that they did not usually concentrate in the lecture room/ theatre. As regards sleeping through the hours of lecture occasionally, a total of 15 (10\%) respondents strongly agreed and 17 (11.3\%) respondents agreed. The above implied that very many of the respondents managed to go for lectures throughout my menstrual period despite the fact that they usually not concentrate in the lecture room/ theatre, but very few of the respondents said that they did not go to the campus during my menstruation due to dysmenorrheal and Menorrhagia occasionally

Table 5. Engaging in Exercise to Ease Your Menstrual Period

\begin{tabular}{|c|c|c|c|c|c|}
\hline $\mathrm{S} / \mathrm{N}$ & VARIABLES & $\begin{array}{l}\text { Strongly } \\
\text { Agreed }\end{array}$ & Agreed & Disagreed & $\begin{array}{l}\text { Strongly } \\
\text { Disagreed }\end{array}$ \\
\hline 1. & $\begin{array}{l}\text { I engage in exercise every day during menstrual } \\
\text { period }\end{array}$ & $10(6.7 \%)$ & $08(5.3 \%)$ & $62(41.3 \%)$ & $70(46.7 \%)$ \\
\hline 2. & I rarely engage in exercise during menstrual period & $10(6.7 \%)$ & $18(12 \%)$ & $54(36 \%)$ & $68(45.3 \%)$ \\
\hline 3. & $\begin{array}{l}\text { I do not engage in exercise at all during menstrual } \\
\text { period }\end{array}$ & $50(33.3 \%)$ & $56(37.3 \%)$ & $34(22.7 \%)$ & $10(6.7 \%)$ \\
\hline 4. & Exercise is the remedy for menstrual pains & $12(8 \%)$ & $24(16 \%)$ & $68(45.3 \%)$ & $46(30.7 \%)$ \\
\hline
\end{tabular}

Table 4 above indicated that 10(6.7\%) respondents strongly agreed and 08 (5.3\%) respondents agreed that they engaged in exercise every day during menstrual period, a total of 10(6.7\%) respondents strongly agreed and 18(12\%) respondents agreed that they rarely engage in exercise during menstrual period while a total of 50(33.3\%) respondents strongly agreed and 56(37.3\%) respondents agreed that they did not engage in exercise at all during menstrual period. As regards the statement that exercise is the remedy for menstrual pains, a total of 12(8\%) respondents strongly agreed and 24(16\%) respondents agreed. The above statement connotes that very many of the respondents did not engage in exercise during menstrual period, but managed to go for lectures despite the fact that they did not concentrate in the lecture room. 


\section{Test of Hypothesis}

(1) Research Hypothesis 1: There is no significantly difference of menorrhagia and dysmenorrhea on academic performance between tertiary institutions female students.

Table 6. T-Test and Percentage Distribution of Significant Difference of Menorrhagia and Dysmenorrhea on Academic Performance between Tertiary Institutions Female Students

\begin{tabular}{llllllll}
\hline Variables & No & Mean & sd & t-value & df & P & Decision \\
\hline College of Education female students & 65 & 3.59 & 0.498 & 0.232 & 18 & 1.06 & NS \\
University female students & 85 & 3.73 & 0.604 & & & & \\
\hline C.05 & & & & & & &
\end{tabular}

Table 5 showed t-test analysis of responses of College of Education female students and University female students on the incidence of dysmenorrheal and menorrhagia. To test if the difference observed in the number of university female students by location were statistically significant; t-test analysis was used. The data analysis showed that the t-test value is 0.232 , is less than $(<) 1.06$ at 0.05 level of significant. Based on this result, the null hypothesis which stated that there is no significant difference of menorrhagia and dysmenorrhea on academic performance between tertiary institutions female students was accepted. Hence, there was no significant difference of menorrhagia and dysmenorrhea on academic performance between tertiary institutions female students.

\section{Discussion}

One of the results of this study revealed that very many female students were aware of dysmenorrhea (severe pain) and menorrhgia (heavy bleeding) during menstruation and related problems. This is contrary to the finding of Hillen et al. (1999), that some young women lack the awareness and understanding of helpful treatment of dysmenorrhoea and other related discomforts of menstrual period, Titilayo et al (2009) that there was no appropriate and no sufficient information about menstrual problems among very many adolescents.

Many of the respondents usually experience dysmenorrhea (severe pain) and menorrhgia (heavy bleeding) during menstruation. This is related to the findings of Campbel et al (1997), It is a serious pain and very severe during menstruation, Hillen et al (1999) which revealed that dysmenorrhea is the most common gynecologic disorder among female adolescents with a prevalence of $60 \%$ to 93\%, and Cakir, Mungan, Karakas, Girisken, and Okten (2007), which reported in a study conducted that the prevalence of dysmenorrhea among the respondents was high with $89.5 \%$.

Many of the respondents 78 (52\%) said that they did not usually concentrate in the lecture room/ theatre, This compliments the earlier researchers El-Gilany et al., (2005) which stated that Dysmenorrhoea and menorrhagia commonly limit concentration in class. While 127 (84.7\%) respondents reported that they managed to go for lectures throughout my menstrual period. This is not in line with the earlier researchers El-Gilany et al., (2005) which stated that Dysmenorrhoea and menorrhagia commonly limit daily home regular task, and attending school.

Another result of the finding indicated that very many of the respondents said that exercise is not the remedy for menstrual pains. This is in line with the findings of the study conducted by Liliwati, Verna, and Khairani,(2007), which stated that the students reported that dysmenorrhoea affected their concentration in class and participation in sports activities and Chantay, Mariam, and Steve(2000), which stated that dysmenorrhea is associated with a negative impact on sports activities of many female adolescents, From the result of the study, it showed that these respondents may be ignorant as regards menstrual disorders.

Reference to results of the verbal interview with 15 female students on dysmenorrhea and menorrhagia, only 12 students said they were usually not comfortable with pain and heavy bleeding during their menstrual period. These did restrain one from being active in academic performance. Five out of the 12 students said they sometimes stayed away campus due to severe pain and heavy bleeding. As regards exercise, only 3 out of the 15 female students said they engaged in exercise frequently, this aided them to have very mild pain during their menstrual period. This is contrary to Chantay, Mariam, and Steve (2000), that dysmenorrhea can cause school absenteeism, and may possibly result to negative effect on academic, and sports activities among many female adolescents 


\section{Conclusion}

Based on the findings of the study, the following conclusions were made:

Many of the respondents were aware of dysmenorrhea and menorrhagia, experienced various symptoms/dysfunction during their menstrual period, agreed that dysmenorrheal and menorrhagia disallowed them to be attentive in class, while some respondents agreed that they usually stay away from lectures due to dysmenonrrhea.

Very many students managed to go to lectures throughout their menstrual period, usually experienced dysmenorrhea (severe pain) and menorrhagia (heavy bleeding) during menstruation, did not engage in exercise at all during menstrual period. It was further revealed that there was a significant difference of dysmenorrheal and menorrhagia on academic performance between tertiary institutions female students.

\section{Recommendation}

The following recommendations were made for this study:

Tertiary institution female students should be made to understand that sports can help ease dysmenorrheal and menorrhagia through the authority.

The Tertiary institution authority should implement compulsory course of practical into university curriculum relating to exercise/sports as compulsory special elective for all female students

Engaging in physical exercise programme as an outcome of Physical fitness could be disseminated to students through the mass media (television, newspaper and radio), posters and magazine e.t.c. by the 3tiers of government

Seminars could be used to disseminate information to students by the Tertiary institution authority.

\section{References}

Alaettin Unsal, Unal Ayranci, Mustafa Tozun, Gul Arslan, \& Elif Calik. (2010). Prevalence of dysmenorrhea and its effect on quality of life among a group of female university students Ups. Journal of Medical Science, 115(2), 138-145. http://dx.doi.org/10.3109/03009730903457218

Banikarim C., Chacko MR., \& Kelder SH. (2000). Prevalence and impact of dysmenorrhea on Hispanic female adolescents. Archives of Pediatrics and Adolescent Medicine. Dec., 154(12), 1226-9. http://dx.doi.org/10.1001/archpedi.154.12.1226

Cagical, J.M. (1990). Sports and Education. The International Bulletin of Physical Education, 60(2), 7-16.

Cakir, M., Mungan, I., Karakas, T., Girisken, I., \& Okten, A. (2007). Menstrual pattern and common menstrual disorders among university students in Turkey. Pediatrics International, 49, 938-942. http://dx.doi.org/10.1111/j.1442-200X.2007.02489.x

Campbell M. A., \& McGrath P J. (1999). Non-pharmacologic strategies used by adolescents for the management of menstrual discomfort. Clin J Pain., 15, 313-20. http://dx.doi.org/10.1097/00002508-199912000-00008

Campbell M. A., \& McGrath P J. (1997). Use of medication by adolescents for the management of menstrual discomfort. Archives of Pediatric Adolescent Medicine. 151(9), 905-912. http://dx.doi.org/10.1001/archpedi.1997.02170460043007

Chantay Banikarim, Mariam R. Chacko \& Steve H. Kelder. (2000). Prevalence and Impact of Dysmenorrhea on Hispanic Female Adolescents FREE Archives of Pediatrics of Adolescent Medicine, 154(12), 1226-1229. http://dx.doi.org/10.1001/archpedi.154.12.1226

Darst, P. W., \& Pangrazi, R. P. (2006). Dynamic physical education for secondary School students (5 ${ }^{\text {th }}$ ed.). San Francisco: Pearson Benjamin Cummings.

Davis, A.R., \& Westhoff, C.L. (2001). Primary dysmenorrheal in adolescent girls and treatment with oral contraceptive. Journal of Pediatric and Adolescent Gynecology, 14, 3-8. http://dx.doi.org/10.1016/S1083-3188(00)00076-0

Dawood, M.Y. (1985). Dysmenorrhoea. Journal of Reproductive Medicine, 30, 154-167.

Durain D. (2004). Primary Dysmenorrhea: Assessment and Management Update. Journal of Midwifery of women in Health, 49, 520-8. http://dx.doi.org/10.1016/S1526-9523(04)00390-3 
El-Gilany, A.H., Badawi, K., \& El-Fedawy, S. (2005). Epidemiology of dysmenorrhoea among adolescent students in Mansoura, Egypt. Eastern Mediterranean Health Journal, 11(1/2), 155-163.

Eryilmaz G., Ozdemir F., \& Pasinlioglu T. (2010). Dysmenorrhea prevalence among adolescents in eastern Turkey: Its effect on school performance and relationships with family and friends. Journal of Pediatric of Adolescent Gynecology, 23, 267-72. http://dx.doi.org/10.1016/j.jpag.2010.02.009

Grant, C., Gallier, L., Fahey, T., Pearson, N., \& Sarangi, J. (2000). Management of menorrhagia in primary care impact on referral and hysterectomy: data from the Somerset Morbidity Project. Journal of Epidemiology and Community Health, 54, 709-713. http://dx.doi.org/10.1136/jech.54.9.709

Guo, L.Y., Shao, L.X., Wang, B.Q., \& Tan, M.T. (1994). Investigation of dysmenorrhea in 1341 female college students. Journal of convalescence and rehabilitation, 9, 31-33.

Hacker NF, Gambone JC, Hobel CJ. Hacker \& Moore's. (2010). Essentials of Obstetrics and Gynecology (5th ed.). Philadelphia, PA: Saunders/Elsevier; 256-7.

Hao, G.R., \& Liu, D. (2000). Analysis of dysmenorrheal of 634 university schoolgirls. Journal of Taishan Medical College, 21, 235-236.

Hillen J., \& Grbavac S. (1999). Primary dysmenorrhea in young western Australian women: prevalence, impact and knowledge of treatment. Journal of Adolescent Health care, 2540-45. http://dx.doi.org/10.1016/s1054-139x(98)00147-5

Hong-Gui Zhou, Zheng-Wei Yang, \& Students Group (2010). Prevalence of dysmenorrhea in female students in a Chinese university: a prospective study. Health, 2(4), 311-314.

Kamatenesi-Mugisha, M., Oryem-Origa, H., \& Olwa-Odyek. (2007). Medicinal plants used in some gynecological morbidity ailments in Western Uganda. African Journal of Ecology, 45(Suppl. 1), 34-40. http://dx.doi.org/10.1111/j.1365-2028.2007.00735.x

Klein Jlitt I. (1981). Epidemiology of adolescent dysmenorrhea. Pediatric, 68, 661- 664

Liasu, A., Orji, E.O., \& Lawani, A. (2008). Menstrual disorder among young female workers and its implication on job performance (case study of Obafemi Awolowo University, Nigeria). Ife Psychologia. An International Journal of Psychology in Africa, 16, 224- 238.

Liliwati I., Verna LKM., \& Khairani O. (2007). Dysmenorrhoea and its Effects on School Activities Among Adolescent Girls in a Rural School in Selangor, Malaysia. Medicine \& Health, 2(1), 42-47.

Nwankwo T.O., Aniebue U.U., \& Aniebue P.N. (2010). Menstrual disorders in adolescent school girls in Enugu, Nigeria. Journal of Pediatric Adolescent Gynecology, 23, 358-63. http://dx.doi.org/10.1016/j.jpag.2010.04.001

Pangrazi R.P. (2004). Dynamic physical education for elementary school children (14 ${ }^{\text {th }}$ ed.). San Francisco: Pearson Benjamin Cummings.

Thomas, K.D., Okonofua, F.E., \& Chiboka, O. (1990). A study of the menstrual patterns of adolescents in Ile-Ife, Nigeria. International Journal of Gynecology \& Obstetrics, 33, 31-34. http://dx.doi.org/10.1016/0020-7292(90)90651-Z

Titilayo A., Banjo O., Agunbiade O.M., \& Lawani A. (2009). Menstrual discomfort and its influence on daily academic activities and psychosocial relationship among undergraduate female students in Nigeria. Tanzania Journal of Health Research, 11(4), 181-188.

Wang, B.G., Chen, S.D., Zhou, W.P., \& Wang, G.Q. (2008). Study on the menstrual periods and health care of female college students in Guangzhou. Chinese Journal of School Doctor, 22, 162-163.

Wong LP., \& Khoo EM. (2010). Dysmenorrhea in a multiethnic population of adolescent Asian girls. International Journal of Gynaecology and Obstetrics, 108, 139-42. http://dx.doi.org/10.1016/j.ijgo.2009.09.018

Yu, Q.H., Zhu, D., Yun, M.Y., \& Kang, X.P. (2008). Investigation of dysmenorrhea status and intervention of Chinese medicine of female undergrad uate students of each nationality. Chinese Journal of Family Planning, $16,478-480$.

Zhan, Q.L. (2003). Menstrual investigation of 506 female college students. Chinese Primary Health Care, 17, 46. 